p-ISSN : 2655-7304

e-ISSN : 6655-8953

\title{
KAJIAN ANALISIS EFISIENSI INDUSTRI PERBANKAN INDONESIA MENGGUNAKAN METODE DISTRIBUTION FREE APPROACH
}

\author{
${ }^{1}$ RAHADIAN A. HAMDANI \\ ${ }^{1}$ Universitas Pendidikan Indonesia, Department of Management, Bandung, Indonesia \\ E-Mail : ${ }^{1}$ rahadian 121@yahoo.com, ${ }^{2}$ nizar hamdani@uniga.ac.id
}

\begin{abstract}
The financial and banking industries in the ASEAN region will be integrated starting in 2020, which is an agreement between ASEAN countries in the implementation of the ASEAN Economic Community (AEC) market. Banks currently operating in all ASEAN countries should further increase the efficiency factor because only efficient banks can compete in the free market. Until now, the Indonesian banking industry still has problems in terms of efficiency. The average ratio of Operating Costs to Operating Income (BOPO) is still high, namely $81.49 \%$ as of December 2017. The Net Interest Margin (NIM) ratio is still above five percent $(5.39 \%)$ as of December 2017 . The NIM ratio is still far away. above the average NIM ratio in the five major ASEAN countries, which is in the range of 50 percent and 3.5 percent.
\end{abstract}

Keywords : Distribution Free Approach, Cost Efficiency, Profit Efficiency, Alternative Efficiency

\section{ABSTRAK}

Industri keuangan dan perbankan di wilayah ASEAN akan diintegrasikan mulai tahun 2020 yang merupakan kesepakatan antar negara ASEAN dalam pemberlakuan pasar ASEAN Economic Community (AEC). Bankbank yang saat ini beroperasi di seluruh negara ASEAN haras lebih meningkatkan faktor efisiensi karena hanya bank yang efisienlah yang dapat bersaing dalam pasar bebas. Industri perbankan Indonesia sampai saat ini masih memiliki masalah dalam hal efisiensi. Rata-rata rasio Biaya Operasional terhadap Pendapatan Operasional (BOPO) masih tinggi yaitu 81,49\% per Desember 2017. Rasio Net Interest Margin (NIM) masih di atas lima persen (5,39\%) per Desember 2017. Rasio NIM tersebut masih jauh di atas rata-rata rasio NIM di lima negara besar ASEAN yang berada pada kisaran angka 50 persen dan 3,5 persen.

Keywords : Distribution Free Approach, Cost Efficiency, Profit Efficiency, Alternative Efficiency 
p-ISSN : 2655-7304

e-ISSN : 6655-8953

\section{INTRODUCTION}

Industri keuangan dan perbankan di wilayah ASEAN akan diintegrasikan mulai tahun 2020. Pengintegrasian ini merupakan kesepakatan antar negara ASEAN dalam pemberlakuan pasar ASEAN Economic Community (AEC). Dengan adanya pengintegrasian sektor keuangan maka persaingan lembaga perbankan antar negara di ASEAN akan semakin meningkat.

Dalam menyambut pengintegrasian sektor keuangan ini, Bank Indonesia sudah melakukan berbagai kajian mengenai ASEAN Banking Integration Framework (ABIF) yang salah satunya adalah kajian mengenai bank berskala ASEAN atau Qualified ASEAN Banks (QAB). QAB merupakan program persiapan dalam mengadapi pengintegrasian pasar lembaga keuangan dan perbankan. Dalam kerangka QAB. Setiap negara anggota ASEAN berhak mengirimkan tiga lembaga perbankannya untuk masuk dan mengembangkan usahanya di negara-negara ASEAN tanpa ada hambatan sedikitpun.

Pada tahun 2014, Bank Indonesia telah memilih dan menetapkan tiga bank yang nasional yang masuk ke dalam program QAB yaitu Bank Mandiri, BRI dan BCA.Oleh karena itu, bank-bank yang saat ini beroperasi di seluruh negara ASEAN haras lebih meningkatkan lagi efisiensinya karena hanya bank yang efisienlah yang dapat bersaing dalam pasar yang terbuka bebas.

Industri perbankan Indonesia sampai saat ini masih memiliki masalah dalam hal efisiensi. Ratarata rasio Biaya Operasional terhadap Pendapatan Operasional (BOPO) masih tinggi yaitu $81,49 \%$ per Desember 2017. Rasio Net Interest Margin (NIM) masih di atas lima persen $(5,39 \%)$ per Desember 2017. Rasio NIM tersebut masih jauh di atas ratarata rasio NIM di lima negara besar ASEAN yang berturut-turut berada pada kisaran angka 50 persen dan 3,5 persen.

Oleh karena itu, industri perbankan Indonesia dituntut untuk bisa lebih efisien lagi. Tingkat BOPO dan NIM industri perbankan Indonesia selama 11 tahun terakhir, relatif tidak banyak mengalami perubahan. Nilai NIM perbankan Indonesia selama 11 tahun terakhir tetap berada di kisaran angka lima persen, sedangkan untuk nilai BOPO, selama 11 tahun terakhir masih ada pada kisaran 84 persen sampai dengan 89 persen walaupun dari sisi pendapatan hampi semua bank di Indonesia mengalami peningkatan. Hal ini disebabkan karena seiring dengan peningkatan pendapatan operasional, biaya operasional bank juga mengalami peningkatan sehingga tidak berpengaruh besar pada nilai BOPO.

Seiring dengan peningkatan pendapatan bankbank di Indonesia juga melakukan ekspansi bisnis dengan menambah berbagai infrastruktur seperti penambahan kantor cabang dan mesin Anjungan Tunai Mandiri (ATM). Oleh karena itu, untuk menilai tingkat efisiensi bank alangkah baiknya jika melihat secara komprehensif dengan memasukan berbagai variabel penilaian tidak hanya sebatas pada nilai BOPO dan NIM saja. Peran bank sebagai lembaga intermediasi harus dilihat secara lebih menyeluruh baik dari aspek pendapatan bank itu sendiri maupun dari aspek biaya yang dikeluarkan oleh bank tersebut. Dengan memasukkan beberapa variabel kinerja keuangan bank maka tingkat efisiensi suatu bank akan bisa dilihat lebih objektif baik dilihat dari sisi pendapatan bank maupun dari sisi biaya.

Pengukuran tingkat efisiensi bank dengan menggunakan pendekatan metode parametrik dan non parametrik ini bukanlah hal yang baru. Akhtar (2010) melakukan penelitian mengenai tingkat efisiensi bank di Pakistan dengan menggunakan data dari tahun 2001 sampai tahun 2006. Metode yang digunakan adalah Data Envelopment Analysis (DEA) dan hasilnya menunjukkan bahwa tingkat efisiensi bank di Pakistan masih rendah.

Repkova dan Miglietti (2014) meneliti tingkat efisiensi biaya dan keuntungan sektor perbankan di Slovakia periode 2003-2012 dengan menggunakan metode Stochastic Frontier Approach (SFA). Dari hasil penelitian mereka diperkirakan nilai efisiensi biaya rata-rata berkisar $29-92$ persen. Sedangkan nilai efisiensi keuntungan rata-rata berkisar antara 56-93 persen. Hasil penelitian mereka juga menunjukkan bahwa bank-bank kecil dan menengah di Slovakia lebih efisien daripada bank-bank besar.

Sillah et al., (2014) melakukan penelitian dengan menganalisis tingkat efisiensi teknis perbankan di Arab Saudi dengan menggunakan model stochastic frontier. Penelitian Sillah et al., (2014) menggunakan 12 bank sebagai sampel selama periode tahun 2000-2011. Bank yang dijadikan sebagai sampel dibedakan menjadi tiga kelompok yaitu bank milik pemerintah, bank milik asing, dan bank syariah. Dari hasil penelitian 
ditemukan perbedaan yang signifikan antara bankbank tersebut dalam hal efisiensi teknis. Bank yang paling efisien adalah bank asing sedangkan bank milik pemerintah kinerja efisiensinya berfluktuasi selama periode penelitian dan jenis bank syariah tidak berbeda secara signifikan dari milik pemerintah.

Di belahan benua Eropa, Banerjee dan Biswajit (2012) menganalisis tingkat efisiensi bank di negaranegara yang baru masuk menjadi anggota Uni Eropa. Banerjee dan Biswajit (2012) mengukur peringkat relatif efisiensi masing-masing negara dan pengaruh struktur kepemilikan terhadap kinerja bank. Teknik yang digunakan adalah DEA, SFA, dan DFA dengan mengukur tingkat efisiensi biaya, keuntungan, dan keuntungan alternatif. Hasil penelitiannya memperlihatkan bahwa teknik penghitungan dan konsep yang berbeda akan menghasilkan hasil yang berbeda untuk peringkat efisiensi, tetapi beberapa pola umum adalah sudah sama. Dari penelitiannya ditemukan bahwa Ceko menjadi negara paling efisien dari sisi teknis dan keuntungan namun terendah dalam hal efisiensi biaya. Sedangkan bankbank di Slovenia dan Estonia menjadi bank paling efisien dari sisi biaya.

Di Indonesia penelitian mengenai tingkat efisiensi bank dengan menggunakan DEA, SFA, dan DFA sudah pernah dilakukan, salah satunya adalah Hadad dkk. (2003). Hadad dkk. (2003) juga pernah melakukan penelitian yang serupa dengan menggunakan metode parametrik (SFA dan DFA). Hasilnya menunjukkan berdasarkan metode parametrik, skor efisiensi DFA lebih beragam dibandingkan dengan skor efisiensi SFA, jika digunakan data bulanan dan data tahunan yang menggabungkan seluruh bank. Namun demikian, bank-bank yang paling efisien yang dihasilkan dengan menggunakan kedua metode adalah sama. Dalam penelitian ini setidaknya ada tiga jenis efisiensi yang akan dilihat dengan menggunakan metode DFA. Ketiga jenis efisiensi tersebut adalah cost efficiency, profit efficiency, dan alternative profit efficiency. Dengan melihat ketiga jenis efisiensi tersebut diharapkan penelitian ini dapat memberikan gambaran yang lebih komprehensi mengenai tingkat efisiensi di industri perbankan Indonesia.

\section{DISTRIBUTION FREE APPROACH}

Efisiensi merupakan konsep yang tidak asing bagi para pelaku ekonomi termasuk para pelaku industri perbankan. Hal ini dikarenakan konsep utama dalam ekonomi adalah mendapatkan keuntungan maksimal dengan biaya tertentu. Menurut Farrel (1957), efisiensi ekonomi dapat dibedakan menjadi dua yaitu efisiensi teknis dan efisiensi alokasi. Efisiensi teknis menurut Koopmans (1951) adalah suatu keadaan dimana peningkatan pada beberapa output membutuhkan penurunan setidaknya satu output lainnya atau membutuhkan peningkatan setidaknya satu input. Dengan kata lain efisiensi teknis adalah pengurangan beberapa input yang membutuhkan setidaknya peningkatan satu input lainnya atau pengurangan setidaknya pada satu output.

Berdasarkan definisi efisiensi kemudian muncul definisi inefisiensi. Inefisiensi adalah suatu posisi dimana seorang produsen dapat memproduksi output yang sama setidaknya dengan kurang dari satu input atau menggunakan input yang sama untuk memproduksi lebih dari setidaknya satu output.

Coelli et al., (1998) menyatakan bahwa konsep efisiensi dibedakan menjadi tiga yaitu technical efficiency, price efficiency dan economic efficiency. Efisiensi teknis mengukur tingkat produksi yang dicapai pada tingkat penggunaan input tertentu. Efisiensi harga atau alokatif mengukur tingkat keberhasilan suatu perusahaan dalam usahanya untuk mencapai keuntungan maksimum yang dicapai pada saat nilai produk marginal setiap faktor produksi yang diberikan sama dengan biaya marginalnya. Efisiensi ekonomis adalah kombinasi antara efisiensi teknis dan efisiensi harga.

Secara lebih jelas, konsep mengenai efisiensi dapat dilihat dalam Gambar 1 yang dikembangkan oleh Farrel (1957). Menurut Farrel untuk menghitung efisiensi bisa dilakukan dengan dua pendekatan yaitu pendekatan input dan pendekatan output. Pendekatan input dijelaskan melalui kurva isocost yang ditunjukkan oleh kurva $\mathrm{AA}^{\prime}$ dan isoquant yang ditunjukkan oleh kurva SS'. Yang dibandingkan adalah dua penggunaan input terhadap satu output dengan asumsi constant return to scale.

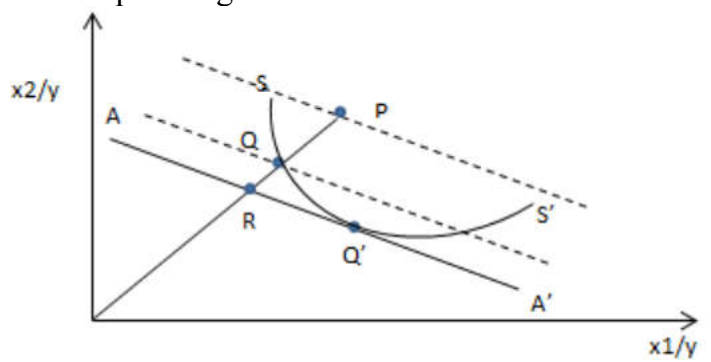

Gambar 1. Efisiensi Teknis \& Alokatif

Dalam gambar tersebut dijelaskan terdapat dua input (x1 dan x2) untuk menghasilkan satu output 
(y). Titik Q' merupakan titik kombinasi input yang paling efisien. Rasio 0Q:0P menjelaskan nilai efisiensi teknis. Sebuah perusahaan secarateknis dikatakan lebih efisien dibandingkan perusahaan lain, apabila dengan penggunaan jenis dan jumlah input yang sama, memperoleh output secara fisik yang lebih tinggi. Rasio 0R:0Q menunjukkan ukuran efisiensi alokatif yaitu ketika suatu perusahaan dapat menggerakkan outputnya dari titik Q ke titik Q' dimana dengan biaya yang lebih rendah dapat menghasilkan output yang sama. Sedangkan efisiensi ekonomi adalah kombinasi antara efisiensi teknis dengan efisiensi alokatif.

Pada pendekatan output melihat seberapa besar peningkatan jumlah output tanpa meningkatkan jumlah penggunaan input. Perbandingannya adalah kedua input terhadap kombinasi output. Kurva yang dilihat adalah kurva kemungkinan produksi dan isorevenue. Di dalam pendekatan output terdapat tiga tipe penambahan output yaitu constant return to scale, decreasing return to scale, dan increasing return to scale. Untuk pendekatan input dan output akan memberikan perhitungan yang setara akan efisiensi teknis di dalam constant return to scale. Tetapi tipe penambahan yang menunjukkan hasil yang berbeda adalah decreasing / increasing return to scale. Inefisiensi yang dihasilkan melalui pendekatan output menunjukkan jumlah output yang dapat ditingkatkan tanpa penambahan input.

Berdasarkan review komprehensif yang dilakukan oleh Berger dan Humphrey (1997) terhadap 130 penelitian tentang efisiensi lembaga keuangan di 21 negara diketahui setidaknya ada dua pendekatan untuk mengukur efisiensi di lembaga perbankan yaitu pendekatan non parametrik dan pendekatan parametrik. Metode yang biasa digunakan untuk pendekatan non parametrik adalah Data Envelopment Analysis (DEA) dan Free Disposal Hull (FDH). Pada pendekatan parametrik, metode yang digunakan adalah Stochastic Frontier Analysis (SFA), Distribution Free Approach (DFA) dan Thick Frontier Approach (TFA). Jika dilihat dari konsep efisiensi dalam industri perbankan maka pendekatan pengukuran nilai efisiensi bank dapat dibedakan menjadi tiga yaitu cost efficiency, profit efficiency, dan alternative profit efficiency.

Cost efficiency mengukur tingkat kedekatan jumlah biaya yang dikeluarkan oleh suatu bank dengan jumlah biaya yang dikeluarkan best practice bank untuk menghasilkan jumlah output yang sama dalam kondisi yang sama. Standard profit efficiency mengukur seberapa dekat sebuah bank kepada tingkat maksimum profit yang mungkin dihasilkan pada tingkat harga-harga input dan output tertentu, sedangkan alternative profit efficiency mengukur seberapa dekat suatu bank kepada perolehan profit maksimum dengan tingkat output tertentu, bukan tingkat harga dari output. Jika dilihat dari hubungan input - output fungsi bank, nilai efisiensi bank dapat diperoleh dengan menggunakan dua pendekatan yaitu the production approach dan the intermediation approach (Sealey dan Lindley, 1977).

Penelitian pengukuran tingkat efisiensi perbankan yang berkembang selama ini lebih banyak menggunakan pendekatan non parametrik Data Envelopment Analysis (DEA), sementara pendekatan parametrik distribution free approach (DFA) masih relatif terbatas. Penelitian Delis et al., (2017) dengan menggunakan metode SFA mencoba memasukkan variabel risiko dalam menghitung efisiensi suatu bank. Hasilnya memperlihatkan adanya trade-off antara tingkat efisiensi dengan tingkat risiko yang dihadapi oleh suatu bank. Penelitian empiris lainnya mengenai tingkat efisiensi adalah dengan memasukkan variabel demografi seperti penelitian dari Nurboja dan Kosak (2017); Dong et al., (2017); Triki et al., (2017); dan Degl'Innocenti et al., (2017).

Penelitian empiris lainnya mengenai tingkat efisiensi yaitu dengan memasukkan unsur waktu seperti yang dilakukan oleh Thilakaweera et al., (2016) yang melihat tingkat efisiensi bank di Srilangka pra dan pasca konflik politik di negara tersebut. Penelitian yang sifatnya pengembangan teori atau metodologi dalam pengukuran tingkat efisiensi tidak begitu banyak. Beberapa penelitian pengembangan teori dan metodologi biasanya dilakukan dengan penambahan adjustment terhadap variabel yang digunakan sebagai instrumen pengukuran. Salah satu contohnya adalah penelitian dari Tsionas dan Mamatzakis (2017) yang memberikan adjustment terhadap variabel biaya input yaitu dengan penambahan biaya perubahan faktor produksi.

Metode DFA adalah salah satu metode penghitungan nilai efisiensi dengan pendekatan parametrik yang dikembangkan oleh Berger (1993). Berger (1993) membangun pendekatan DFA untuk 
menggantikan beberapa asumsi statistik yang ketat dalam pendekatan SFA dengan asumsi sederhana dalam dekomposisi residual. Pendekatan ini mengasumsikan bahwa perbedaan biaya (dalam konteks efisiensi biaya) yang berkaitan dengan inefisiensi biaya adalah stabil sepenjang waktu dimana komponen acak (random error) bervariasi dan cenderung mendekati rata-ratanya yaitu nol.

Fungsi biaya dengan pendekatan DFA dapat dituliskan dalam bentuk di bawah ini:

$\mathrm{C}=\mathrm{C}\left(\mathrm{w}, \mathrm{y}, \mathrm{z}, \mathrm{v}, \mathrm{u}_{\mathrm{c}}, \mathrm{e}_{\mathrm{c}}\right)$

Dimana

$\mathrm{C}$ adalah variabel biaya

$\mathrm{w}$ adalah variabel harga input

y adalah kuantitas output

$\mathrm{Z}$ adalah kuantitas fixed netputs

$\mathrm{v}$ adalah kondisi lingkungan

uc adalah faktor inefisiensi

$\mathrm{S}_{\mathrm{C}}$ menggambarkan random error.

Fungsi keuntungan dengan pendekatan DFA dapat dituliskan dalam bentuk di bawah ini:

$\mathrm{n}=£\left(\mathrm{w}, \mathrm{p}, \mathrm{z}, \mathrm{v}, \mathrm{u}_{\mathrm{c}}, \mathrm{G}_{\mathrm{c}}\right)$

Dalam fungsi keuntungan hampir semua variabel sama dengan variabel pada fungsi biaya kecuali $\mathrm{n}$ yang menggambarkan variabel keuntungan, dan $p$ yang menggambarkan variabel harga output. Fungsi keuntungan lainnya dengan pendekatan DFA dapat dituliskan dalam bentuk di bawah ini:

$$
\mathrm{n}=\mathrm{e}\left(\mathrm{w}, \mathrm{y}, \mathrm{z}, \mathrm{v}, \mathrm{u}_{\mathrm{c}}, \mathrm{E}_{\mathrm{c}}\right)
$$

Dalam fungsi keuntungan lainnya hampir semua variabel sama dengan variabel keuntungan kecuali variabel $p$ yang menggambarkan variabel harga output diganti dengan variabel y yang menggambarkan kuantitas output.

\section{RESEARCH METHOD}

Penelitian ini menggunakan data sekunder, yakni laporan keuangan publikasi bank yang terdapat dalam Direktori Perbankan Indonesia (DPI) yang diterbitkan oleh Otoritas Jasa Keuangan (2016). Data yang digunakan adalah data publikasi bank selama 12 tahun yaitu tahun 2007 - 2019 . Periode tahun 2007 - 2019 diambil sebagai tahun pengamatan karena selama periode tersebut bank dinilai sudah melalui tahap recovery pasca krisis ekonomi tahun 1997/1998.

Data yang digunakan adalah data panel yang berasal dari seluruh bank umum di Indonesia periode tahun 2007 - 2019 yang terdiri dari Bank Persero, Bank Swasta Devisa, Bank Swasta Non Devisa,
Bank Campuran, Bank Asing dan Bank Pembangunan Daerah (BPD). Jumlah total bank yang diteliti sebanyak 98 unit.

Variabel-variabel yang digunakan dalam penelitian ini disesuaikan dengan laporan keuangan bank yang berlaku di Indonesia dari tahun 2007 sampai dengan tahun 2019. Variabel-variabel yang digunakan juga berbeda untuk setiap pendekatan. Variabel yang digunakan pendekatan Profit Effciciency, Cost Efficiency dan Alternative Profit Efficiency dapat dilihat dalam Tabel 1.

Dalam rangka kontrol heteroskedastisitas dalam setiap persamaan maka setiap variabel dalam penelitian ini dibagi oleh variabel total aset. Selain itu, perlakuan ini diharapkan dapat memberikan interpretasi yang lebih baik secara ekonomi. Dalam manajemen perbankan, Return on Asset (ROA) menjadi salah satu indikator utama dalam pencapaian tujuan bank. Oleh karena itu, dalam penelitian ini beberapa variabel dibagi dengan jumlah total aset di masing-masing bank.

Tabel 1. Variabel Penelitian

\begin{tabular}{|c|c|c|c|}
\hline No & Categogy & Name & Symbol \\
\hline \multicolumn{4}{|c|}{ Profit Efficiency Approach } \\
\hline 1 & Dependent & Operational Income & $\pi$ \\
\hline 2 & & Interest Expense & W \\
\hline 3 & & Interest Income & $\mathrm{P}$ \\
\hline 4 & & Net Commitment & $\mathrm{Z1}$ \\
\hline 5 & & Physical Capital & $\mathrm{Z} 2$ \\
\hline 6 & Independent & Asset & $\mathrm{Z3}$ \\
\hline 7 & & Non Performing Loan & NPL \\
\hline \multicolumn{4}{|c|}{ Cost \& Alternate Efficiency Approach } \\
\hline 1 & Dependent & Operational Income & $\pi$ \\
\hline 2 & & Operational Expense & $\mathrm{c}$ \\
\hline 3 & & Interest Expense & $\mathrm{W}$ \\
\hline 4 & & Total Credit & Y1 \\
\hline 5 & & Productive Assets & Y2 \\
\hline 6 & & Net Commitment & Z1 \\
\hline 7 & & Physical Capital & $\mathrm{Z2}$ \\
\hline 8 & Independent & Asset & $\mathrm{Z3}$ \\
\hline 9 & & Non Performing Loan & NPL \\
\hline
\end{tabular}

Berdasarkan hubungan input - output fungsi bank, pendekatan yang digunakan dalam penelitian ini adalah the intermediation approach. Pendekatan intermediasi memandang bank sebagai intermediator dimana bank berfungsi merubah dan mentransfer aset-aset finansial dari unit-unit surplus menjadi unit-unit defisit. Dalam hal ini input-input institusional adalah pembayaran bunga pada deposit, dengan output yang diukur dalam bentuk kredit 
pinjaman (loans) dan investasi finansial (financial investments).

Dalam penelitian ini penggunaan model DFA akan diterapkan dengan pendekatan cost efficiency, standard profit efficiency, dan alternative profit efficiency. Secara matematis model DFA dengan pendekatan cost efficiency dapat mengikuti perhitungan dari Berger dan Mester (1997) sebagaimana formula 1 berikut : Cost $E F F^{b}=\frac{\hat{c}^{\min }}{c^{b}}=\frac{\exp \left[f\left(w^{b}, y^{b}, z^{b}, y^{b}\right)\right] x \exp \left[\ln \hat{n}_{c}^{\min }\right]}{\exp \left[f\left(w^{b}, y^{b}, z^{b}, v^{b}\right) \mid x \exp \left[\ln \hat{u}_{c}^{b}\right]\right.}=\frac{\hat{u}_{c}^{\min }}{\hat{u}_{c}^{b}}$

Nilai cost efficiency akan berkisar dalam interval (0-1) dimana nilai efisiensi satu menunjukkan bahwa bank tersebut merupakan bank yang paling efisien. Model matematis di atas memiliki galat (error term). Setiap galat mempunyai dua komponen, yaitu komponen acak (random effect) dan komponen inefisiensi teknis. Untuk memahami hal tersebut, menurut Berger dan Mester (1997) dikembalikan pada fungsi biaya dan profit dimana inefisiensi dan random error dapat dipisahkan dari fungsi biaya atau profit inti. Inefisiensi uc dan error term sc diasumsikan membentuk fungsi biaya dan profit secara multiplikatif sehingga persamaan biaya dan profit dapat dituliskan dalam bentuk logaritma natural sebagaimana formula 2 berikut:

$$
\ln C=f(w, y, x, v)+\ln u_{c}+\ln \varepsilon_{c}
$$

Dimana :

InC : total biaya (logaritma natural dari total biaya) dari bank ke-i;

$\mathrm{w}, \mathrm{y}, \mathrm{z}, \mathrm{v}$ : sebuah vektor (transformasi dari) kuantiatas input output dari unit pengambil keputusan ke-i;

$\ln \varepsilon \mathrm{c}$ : variabel acak yang diasumsikan independent, identical dan normal distribution (iid), $\mathrm{N}\left(0, \sigma \mathrm{v}^{2}\right)$, dan variabel independen $\ln u \quad$ yang merupakan variabel acak non negatif yang digunakan untuk mengukur tingkat inefisiensi teknis.

Model DFA dengan pendekatan standard profit efficiency yang mengikuti pendekatan Berger adalah sebagai berikut :

$$
\text { Std } \pi E F F^{b}=\frac{a \pi^{b}}{a \pi^{\max }}=\frac{\left\{\exp \left[f\left(w^{b}, p^{b}, z^{b}, y^{b}\right) x \exp \left[\ln a_{a \pi}^{b}\right]\right]\right]-\theta}{\left\{\exp \left[f\left(w^{b}, p^{b}, z^{b}, y^{b}\right) X \exp \left[\ln a_{a \pi}^{\operatorname{man}}\right]\right]\right\}-\theta}
$$

Dimana semua komponennya sama dengan model cost efficiency hanya ada perubahan pada variabel dependen dan variabel independennya yaitu dari biaya operasional menjadi keuntungan operasional dan variabel kuantitas output menjadi harga output (p). Di samping itu, pada model standard profit efficiency ada penambahan konstanta $\theta$, yang ditambahkan kepada variabel pendapatan setiap bank sehingga tidak ada bentuk logaritma natural yang nilainya nol sehingga persamaannya dapat dituliskan sebagai berikut:

$$
\ln (\pi+\theta)=f(w, p, x, v)+\ln u_{\pi}+\ln \varepsilon_{\pi}
$$

Sedangkan untuk model DFA dengan pendekatan alternative profit efficiency adalah sebagai berikut :

$$
\text { Alt } \pi E F F^{b}=\frac{a \pi^{b}}{a \tilde{\pi}^{\max }}=\frac{\left\{\exp \left[f\left(w^{b}, y^{b}, x^{b}, w^{b}\right) x \exp \left[\ln \hat{u}_{a x}^{b}\right]\right]\right\}-\theta}{\left\{\exp \left[f\left(w^{b}, y^{b}, x^{b}, v^{b}\right) x \exp \left[\ln \hat{u}_{a \pi}^{M a x} x\right]\right\}-\theta\right.}
$$

Dimana semua komponennya sama dengan model cost efficiency hanya ada perubahan pada variabel dependennya yaitu dari biaya operasional menjadi keuntungan operasional. Di samping itu, pada model alternative profit efficiency ada penambahan konstanta $\theta$, yang ditambahkan kepada variabel pendapatan setiap bank sehingga tidak ada bentuk logaritma natural yang nilainya nol sehingga persamaannya dapat dituliskan sebagai berikut:

$$
\ln (\pi+\theta)=f(w, y, x, v)+\ln u_{a \pi}+\ln \varepsilon_{a \pi}
$$

Efisiensi biaya dengan menggunakan DFA mengukur seberapa dekat biaya dari suatu bank dengan biaya terendah yang dibutuhkan untuk memproduksi output yang sama pada kondisi yang sama. Sedangkan untuk efisiensi profit adalah mengukur seberapa dekat profit yang didapat oleh suatu bank dengan profit tertinggi yang dihasilkan dari produksi yang sama pada kondisi yang sama.

Pengukuran efisiensi biaya diturunkan dari fungsi biaya dimana biaya variabel tergantung dari harga dari input variabel, kuantitas dari output, faktor inefisiensi, dan random error. Untuk pengukuran efisiensi profit diturunkan dari fungsi profit dimana profit yang diperoleh tergantung dari harga input variabel, kuantitas dari output, faktor inefisiensi, dan random error.

Fungsi persamaan alternative profit efficiency menyerupai fungsi persamaan biaya dimana inefisiensi dan random error dapat dipisahkan dari biaya inti. Inefisiensi, $\mathrm{u}_{\mathrm{c}}$, dan error term $\mathrm{s}_{\mathrm{c}}$ diasumsikan membentuk fungsi alternative profit secara multiplikatif sehingga persamaannya dapat dituliskan dalam bentuk logaritma natural seperti dalam persamaan 4. Namun semua variabel dalam penelitian ini sudah dibagi dengan variabel total aset sehingga semua variabel sudah berbentuk rasio. Dalam kondisi seperti ini maka persamaannya tidak ditulis dalam bentuk logaritma natural sehingga penulisan persamaannya adalah :

Persamaan fungsi cost efficiency : 


$$
C=f(w, y, x, v)+u_{c}+\varepsilon_{c}
$$

Persamaan fungsi profit efficiency :

$\pi=f(w, p, x, v)+u_{\pi}+\varepsilon_{\pi}$

Persamaan fungsi alternative efficiency: $\pi=f(w, y, x, v)+u_{\pi}+\varepsilon_{\pi}$

Dalam perlakuan terhadap komponen galatnya, pendekatan DFA mengasumsikan bahwa perbedaan biaya (dalam konteks biaya) yang berkaitan dengan inefisiensi biaya dan perbedaan profit (dalam konteks profit) yang berkaitan dengan inefisiensi profit, adalah stabil sepanjang waktu, dimana komponen acak (random error) bervariasi dan cenderung mendekati rata-ratanya, yaitu nol. Sehingga perbedaan (residual) tersebut dianggap sebagai inefficiency term. Namun sepanjang waktu tersebut, nilai efisiensi dianggap masih memiliki komponen error. Untuk menghilangkan komponen error tersebut, nilai residual yang tertinggi dan yang terendah dari periode penelitian dihilangkan (truncated). Setelah proses truncated tadi, nilai inefisiensi diperoleh dengan membuat rata-rata dari total residual yang telah mengalami truncated.

\section{RESULT AND DISCUSSION}

\section{A. Cost Efficiency}

Pengukuran nilai cost efficiency dari setiap bank menggunakan enam variabel yaitu biaya operasional, total kredit, aktiva produktif selain kredit, net komitmen - kontijensi, modal fisik, dan NPL. Berdasarkan hasil analisis regresi data panel model Fixed Effect didapat fungsi biaya sebagai berikut:

$\mathrm{C}=0,01378+0,24412 \mathrm{~W}+0,05875 \mathrm{Yx}+0,00310 \mathrm{Y} 2-$ $0,000231 \mathrm{Zx}+1,2171 \mathrm{Z} 2+0,000265 \mathrm{NPL}$

Dari 98 bank yang beroperasi selama 12 tahun terakhir, rata-rata cost efficiency bank di Indonesia adalah 0,7972. Nilai maksimum cost efficiency bank berdasarkan penghitungan DFA adalah 1,000 dan nilai minimumnya adalah 0,491254 .

Tabel 2. Statistik Deskriptif Cost Efficiency Bank Di Indonesia
Deviation maka hasilnya dapat dilihat dalam Tabel 3. Dari Tabel 3 dapat diketahui bahwa terdapat tujuh unit bank yang termasuk ke dalam kategori bank dengan efisiensi tinggi. Sebagian besar bank masuk ke dalam kategori efisiensi sedang yaitu 75 unit bank atau 76,53 persen dari total bank yang diteliti, sedangkan bank yang termasuk ke dalam kategori efisiensi rendah hanya sepuluh unit atau 10,20 persen dari total bank yang diteliti.

Tabel 3. Distribusi Normal Cost Efficiency
\begin{tabular}{|c|c|c|c|}
\hline $\begin{array}{c}\text { Efficiency } \\
\text { Value }\end{array}$ & Freq & $\mathbf{\%}$ & Note \\
\hline $\mathrm{NE}<0.6713937$ & 13 & 13,27 & Efisiensi Rendah \\
\hline $0.6713937<\mathrm{NE}<0.7844228$ & 75 & 76,53 & Efisiensi Sedang \\
\hline $\mathrm{NE}>0.7844228$ & 10 & 10,20 & Efisiensi Tinggi \\
\hline
\end{tabular}

Sumber : Hasil Olahan, 2019

Jika tingkat efisiensi bank dikelompokkan ke dalam kelompok jenis bank maka hasilnya dapat dilihat seperti dalam Tabel 4 . Kelompok bank yang paling efisien adalah kelompok bank BUMN dengan rata-rata nilai efisiensi sebesar 0.7540 disusul oleh kelompok bank Devisa dengan nilai efisiensi 0.7467. Kelompok bank yang nilai efisiensinya paling rendah adalah kelompok bank campuran dengan nilai efisiensi 0.6557. Namun walaupun rata-rata nilai efisiensi bank campuran paling rendah namun rata-rata nilai efisiensinya masih berada pada range efisiensi sedang.

Tabel 4. Rata-Rata Nilai Cost Efficiency Berdasarkan

\begin{tabular}{|l|c|}
\multicolumn{2}{|c|}{ Kelompok Bank } \\
\hline Bank Campuran & Efficiency Value \\
\hline Bank Asing & 0.6557 \\
\hline Bank Pembangunan Daerah & 0.6894 \\
\hline BUMN & 0.7158 \\
\hline Bank Devisa & 0.7540 \\
\hline Bank Non Devisa & 0.7467 \\
\hline Sumber : Hasil Olahan, 2019 & 0.7024 \\
\hline
\end{tabular}

Deviaton dilihat secara agregat, tingkat cost 0,055sficiency seluruh bank yang beroperasi di Indonesia sampai saat ini masih belum begitu baik. Berdasarkan kelompok bank, tidakada kelompok bank yang memiliki nilai efisiensi di atas 0,8 . Rendahnya cost efficiency dalam industri perbankan Indonesia bisa disebabkan oleh dua hal (joint hypothesis) yaitu (1) bank-bank yang beroperasi di Indonesia memang belum efisien, (2) bank-bank
Jika nilai cost efficiency bank dikelompokkan ke dalam tiga kategori yaitu tingkat efisiensi tinggi, sedang, dan rendah dengan menggunakan metode mean \pm Standard 
masih berada pada tahapan ekspansi usaha sehingga masih banyak mengeluarkan biaya.

Oleh karena itu, dalam menyimpulkan apakah suatu bank efisien atau tidak maka haras dilihat apakah bank tersebut sedang melakukan ekspansi usaha atau tidak seperti pembuakaan kantor cabang baru, pengembangan teknologi baru, atau penambahan sarana dan pra sarana perbankan. Bank-bank yang beroperasi secara tidak efisien maka dituntut untuk bisa meningkatkan cost efficiencynya. Namun, khusus untuk bank-bank yang sedang melakukan ekspansi usaha, seperti membuka jaringan baru atau sedang menjalankan instruksi pemerintah dalam hal menjadi agen pembangunan di daerahdaerah yang tidak efisien, pemerintah beserta OJK harus bisa memakluminya. Namun tentunya untuk bank-bank yang sedang melakukan ekspansi usaha, pemakluman tersebut tidak boleh diberikan secara terus menerus. Pemerintah beserta OJK harus memberikan batasan waktu sehingga ketika tahapan ekspansi tersebut selesai maka bank tersebut harus bisa beroperasi secara efisien.

Perlakuan khusus harus diberikan kepada bankbank yang menjalankan fungsi sebagai agen pembangunan seperti bank-bank BUMN. Selama ini hanya bank BUMN yang membuka cabang sampai ke daerah pelosok. Hal ini dilakukan bukan karena faktor pertimbangan usaha melainkan lebih karena menjalankan fungsi dan peran negara dalam pemerataan pembangunan. Bila tidak ada bank yang masuk ke daerah-daerah pelosok tersebut maka bisa dipastikan perekonomian di daerah pelosok tersebut tidak akan berkembang baik

\section{B. Profi Efficiency}

Pengukuran nilai profit efficiency bank dalam penelitian ini menggunakan enam variabel yaitu pendapatan operasional, harga beban bunga, harga output, net komitmen - kontijensi, modal fisik, dan NPL. Berdasarkan hasil analisis regresi data panel model Fixed Effect didapat fungsi keuntungan sebagai berikut :

$\pi=1,005212-3,17899 \mathrm{~W}+9,482123 \mathrm{P}-0,0023987 \mathrm{Zx}+$ $4,01798 \mathrm{Z} 2+0,007535 \mathrm{NPL}$

Dari persamaan di atas diperoleh rata-rata nilai profit efficiency 98 bank selama 12 tahun terakhir adalah 0,894167 .

Tabel 5. Statistik Deskriptif Profit Efficiency Bank Di Indonesia

\begin{tabular}{|c|c|c|c|c|c|}
\hline Efficiency & 98 & 0,6147994 & 1,0000 & 0,8194167 & 0,0680168 \\
\hline Valid N & 98 & & & & \\
\hline
\end{tabular}

Sumber : Hasil Olahan, 2019

Jika nilai profit efficiency 98 bank dikelompokkan ke dalam tiga kategori yaitu tingkat efisiensi tinggi, sedang, dan rendah sebagaimana dalam cost efficiency dengan menggunakan metode mean \pm Standard Deviation maka hasilnya dapat dilihat dalam Tabel 6. Dari Tabel 6 dapat diketahui bahwa terdapat 10 unit bank yang termasuk ke dalam kategori bank dengan efisiensi tinggi. Sebagian besar bank masuk ke dalam kategori efisiensi sedang yaitu 67 unit atau 68,37 persen dari total bank yang diteliti, sedangkan bank yang termasuk ke dalam kategori efisiensi rendah berjumlah 16 unit atau 16,33 persen dari total bank yang diteliti.

\begin{tabular}{|c|c|c|c|}
\hline $\begin{array}{c}\text { Efficiency } \\
\text { Value }\end{array}$ & Freq & $\%$ & Note \\
\hline $\mathrm{NE}<0,75138199$ & 15 & 15,31 & Efisiensi Rendah \\
\hline $0,75138199<\mathrm{NE}<0,8875226$ & 67 & 68,37 & Efisiensi Sedang \\
\hline $\mathrm{NE}>0,8875226$ & 16 & 16,33 & Efisiensi Tinggi \\
\hline
\end{tabular}

Sumber : Hasil Olahan, 2019

Dibandingkan dengan rata-rata nilai cost efficiency, jumlah bank yang kurang efisien dari sisi profit efficiency lebih banyak. Bank yang kurang efisien dari sisi biaya berjumlah delapan unit sedangkan bank yang kurang efisien dari sisi profit efficiency berjumlah 10 unit. Bank yang berada di kelompok efisiensi sedang relatif lebih sedikit yaitu 67 bank atau 68,37 persen padahal bank yang berada di kelompok ini dari sisi biaya berjumlah 75 unit atau 76,53 persen dari total seluruh bank.

Jika tingkat profit efficiency bank dikelompokkan ke dalam kelompok enam jenis bank sebagaimana pada cost efficiency, maka hasilnya dapat dilihat seperti dalam Tabel 7. Kelompok bank yang paling efisien masih berasal dari kelompok bank asing dengan rata-rata nilai efisiensi sebesar 0,9209 disusul oleh kelompok bank campuran dengan nilai profit efficiency sebesar 0,8495. Namun, berbeda dengan cost efficiency, kelompok bank yang nilai profit efficiency-nya paling rendah adalah kelompok bank BPD yang memiliki nilai efisiensi 0,7675. Kelompok bank StdBUMN yang pada cost efficiency 
berada di pereingkat pertama, pada kategori profit efficiency berada pada peringkat lima dengan nilai efisiensi 0,7947.

Tabel 7. Rata-Rata Nilai Profit Efficiency Berdasarkan Kelompok Bank

\begin{tabular}{|l|c|}
\hline \multicolumn{1}{|c|}{ Bank Name } & Efficiency Value \\
\hline Bank Campuran & 0.8495 \\
\hline Bank Asing & 0.9209 \\
\hline Bank Pembangunan Daerah & 0.7675 \\
\hline BUMN & 0.7947 \\
\hline Bank Devisa & 0.8179 \\
\hline Bank Non Devisa & 0.8450 \\
\hline \multicolumn{2}{|l}{ Sumber : Hasil Olahan, 2019 }
\end{tabular}

Kelompok bank yang memiliki nilai efisiensi di atas rata-rata ada empat kelompok bank yaitu bank asing, bank campuran, bank non devisa, dan bank devisa. Nilai profit efficiency kelompok bank BUMN dan BPD masih berada di bawah nilai rata-rata profit efficiency seluruh bank. Tingginya nilai profit efficiency bank-bank asing di Indonesia bisa dikatakan cukup wajar. Hal ini disebabkan karena ketika bank-bank asing masuk ke Indonesia mereka telah memiliki pangsa pasar sendiri.

Bank-bank asing biasanya masuk ke Indonesia untuk menyokong industri tertentu yang berasal dari kelompok atau negara tertentu yang biasanya memiliki skala usaha yang sangat besar. Dengan biaya operasional yang relatif lebih kecil dibandingkan dengan bank-bank lainnya, bank-bank asing mendapatkan keuntungan yang jauh lebih besar sehingga profit efficiency-nya lebih tinggi dibandingkan bank-bank lainnya.

Sebaliknya terjadi pada bank-bank BUMN. Bank-bank BUMN yang notabene bank pemerintah harus menjalankan fungsi sebagai agen pembangunan sehingga seringkali masuk ke sektorsektor yang tidak begitu menguntungkan yang biasanya tidak dimasuki oleh bank-bank lain. Sekali lagi hal ini dilakukan atas dasar pertimbangan pemerataan pembangunan sehingga sektor-sektor yang selama ini tidak tersentuh oleh lembaga perbankan bisa memanfaatkan lembaga perbankan yaitu melalui bank-bank milik pemerintah. Oleh karena itu, sangat wajar jika bankbank BUMN tidak memiliki nilai profit efficiency yang bagus dibandingkan bank-bank lain.

\section{Alternate Profit Effiency}

Menurut Berger (1994) penggunaan ukuran efisiensi alternative profit efficiency ini lebih cocok digunakan untuk lingkungan bisnis bank yang tidak berada dalam kondisi persaingan sempurna seperti halnya di Indonesia. Pengukuran nilai alternative profit efficiency dalam penelitian ini menggunakan tujuh variabel yaitu pendapatan operasional, harga beban bunga, total kredit, aktiva produktif selain kredit, net komitmen kontijensi, modal fisik, dan NPL. Berdasarkan hasil analisis regresi data panel model Fixed Effect didapat fungsi alternative profit efficiency sebagai berikut :

$\pi$ alt $=1,7807+3,9880 \mathrm{~W}-0,36030 \mathrm{Yx}+0,002405 \mathrm{Y} 2-$ $0,002209 \mathrm{Zx}+10,7461 \mathrm{Z} 2-0,010105 \mathrm{NPL}$

Dari persamaan di atas dapat diperoleh ratarata nilai alternative profit efficiency 98 bank dalam selama 12 tahun terakhir (20072019) yaitu 0,8781820. Nilai ini lebih besar dibandingkan dengan nilai profit efficiency.

Tabel 8. Statistik Deskriptif Alternate Profit Efficiency Bank Di

\begin{tabular}{|c|c|c|c|c|c|}
\hline & N & Min & Max & Mean & $\begin{array}{c}\text { Std. } \\
\text { Deviaton }\end{array}$ \\
\hline Efficiency & 98 & 0,592117 & 1.000 & 0,8781820 & 0,0658197 \\
\hline Valid N & 98 & & & & \\
\hline
\end{tabular}

Sumber : Hasil Olahan, 2019

Jika nilai alternative profit efficiency 98 bank dikelompokkan ke dalam tiga kategori sebagaimana pada dua kategori efisiensi sebelumnya yaitu tingkat efisiensi

tinggi, sedang, dan rendah dengan menggunakan metode mean \pm Standard Deviation maka hasilnya dapat dilihat dalam Tabel 9. Dari Tabel 9 dapat diketahui bahwa hanya terdapat sepuluh unit bank yang termasuk ke dalam kategori bank dengan efisiensi tinggi atau hanya 10,20 persen dari 98 bank yang diteliti. Sebagian besar bank masuk ke dalam kategori efisiensi sedang yaitu 78 unit atau 79,59 persen dari total bank yang diteliti. Sedangkan bank yang termasuk ke dalam kategori efisiensi rendah berjumlah sepuluh unit atau sekitar 10,20 persen dari total bank yang diteliti.

Tabel 9. Distribusi Normal Cost Efficiency

\begin{tabular}{|l|c|c|c|}
\hline \multicolumn{1}{|c|}{$\begin{array}{c}\text { Efficiency } \\
\text { Value }\end{array}$} & Freq & $\%$ & Note \\
\hline $\mathrm{NE}<0,812422$ & 10 & 10,20 & Efisiensi Rendah \\
\hline $\begin{array}{l}0,812422<\mathrm{NE}< \\
0,9439918\end{array}$ & 78 & 79,59 & Efisiensi Sedang \\
\hline $\mathrm{NE}>0,9439918$ & 10 & 10,20 & Efisiensi Tinggi \\
\hline
\end{tabular}

Sumber : Hasil Olahan, 2019

Jika tingkat alternative profit efficiency bank dikelompokkan ke dalam kelompok enam jenis bank sebagaimana pada cost efficiency dan profit 
efficiency, maka hasilnya dapat dilihat seperti dalam Tabel 10. Kelompok bank yang paling efisien adalah kelompok bank asing dengan rata-rata nilai efisiensi sebesar 0,9392 disusul oleh kelompok bank campuran di peringkat kedua dengan nilai alternative profit efficiency sebesar 0,9372. Dalam pengukuran alternative profit efficiency, kelompok bank BPD masih berada di peringkat ketiga di bawah kelompok bank asing dan bank campuran dengan nilai efisiensi 0,8857, sedangkan kelompok bank BUMN berada di peringkat keempat dengan nilai efisiensi 0,8741 . Kelompok bank dengan nilai efisiensi terendah adalah kelompok bank non devisa dengan nilai efisiensi 0,8560 . Kelompok bank devisa berada di peringkat ke kelima dengan nilai efisiensi sebesar 0,8631 .

Tabel 10. Rata-Rata Nilai Alternate Profit Efficiency Berdasarkan Kelompok Bank

\begin{tabular}{|l|c|}
\hline \multicolumn{1}{|c|}{ Bank Name } & Efficiency Value \\
\hline Bank Campuran & 0.9372 \\
\hline Bank Asing & 0.9392 \\
\hline Bank Pembangunan Daerah & 0.8857 \\
\hline BUMN & 0.8741 \\
\hline Bank Devisa & 0.8631 \\
\hline Bank Non Devisa & 0.8560 \\
\hline
\end{tabular}

Sumber : Hasil Olahan, 2019

Rendahnya nilai efisiensi bank-bank BUMN diduga kuat karena menjalankan fungsi sebagai agen pembangunan pemerintah, rendahnya tingkat efisiensi ini harus tetap diteliti lebih mendalam apakah memang karena menjalankan fungsi sebagai agen pembangunan tersebut ataukah karena operasional yang tidak efisien. Tidak menutup kemungkinan rendahnya nilai efisiensi bank-bank BUMN dalam menghasilkan keuntungan juga disebabkan karena kegiatannya yang tidak efisien.

Pemerintah harus bisa membedakan mana bank BUMN yang tidak efisien karena operasional yang tidak efisien dan mana bank yang tidak efisien karena menjalankan fungsi sebagai agen pembangunan. Dengan mengetahui penyebab dari ketidakefisienan tersebut maka pemerintah bisa mengambil kebijakan yang tepat terhadap bankbank milik pemerintah.

Temuan dalam penelitian ini semakin menegaskan bahwa industri perbankan di Indonesia masih belum bisa dikatakan efisien sebagaimana penelitian-penelitian sebelumnya. Abidin dan Endri (2009) meneliti mengenai tingkat efisiensi teknis Bank Pembangunan Daerah (BPD) dengan menggunakan metode DEA. Hasil penelitian Abidin dan Endri (2009) tersebut menghasilkan kesimpulan bahwa tingkat efisiensi 26 BPD di Indonesia belum mencapai tingkat efisiensi yang optimal (100\%). Endri (2015) melakukan penelitian kembali mengenai tingkat efisiensi bank di Indonesia yaitu bank yang listing di Bursa Efek Indonesia (BEI). Sama halnya dengan penelitian sebelumnya, bank-bank yang sudah listing di BEI juga masih belum bisa mencapai tingkat efisiensi yang optimal.

Masih belum optimalnya tingkat efiensi bank di Indonesia juga pernah dikemukakan oleh Hidayati, dkk (2015). Mereka meneliti tingkat efisiensi bank Syariah di Indonesia dengan menggunakan metode DEA dan pendekatan intermediation approach serta input oriented. Hasilnya memperlihatkan bahwa bank-bank syariah di Indonesia masih belum bisa dikatakan efisien. Hal yang sama juga dikemukakan oleh

Zuhroh et al., (2015). Dengan menggunakan metode SFA dan tiga sampel bank syariah dan 19 bank konvensional yang sudah listing di BEI mereka menemukan bahwa tingkat efisiensi bank syariah lebih rendah dari bank konvensional.

Dengan menggunakan metode DFA dan melibatkan hampir seluruh bank yang beroperasi selama 12 tahun terakhir, hasil penelitian yang dilakukan oleh peneliti mengkonfirmasi dan memperkuat berbagai penelitian mengenai tingkat efisiensi bank di Indonesia sebelumnya. Secara keseluruhan baik cost efficiency maupun profit efficiency, bank-bank yang beroperasi di Indonesia masih belum optimal. Ketidakoptimal efisiensi ini terjadi di seluruh kelompok bank baik bank BUMN, swasta, BPD, asing, maupun campuran.

\section{CONCLUTION}

Secara keseluruhan tingkat efisiensi industri perbankan di Indonesia masih belum optimal. Dilihat dari sisi cost efficiency, 98 bank umum yang beroperasi selama 12 tahun terakhir (2007 - 2019), rata-rata nilai cost efficiency bank di Indonesia adalah 0,72897. Hal ini menandakan bahwa dari sisi cost efficiency bankbank yang beroperasi di Indonesia masih belum optimal. Kelompok bank yang paling efisien adalah bank BUMN diikuti oleh bank devisa dan non devisa. Rendahnya tingkat cost efficiency bank-bank di Indonesia bisa disebabkan oleh salah satu atau dua hal sekaligus yaitu operasional bank yang tidak efisien dan atau bank sedang melakukan ekspansi usaha sehingga banyak pengeluaran yang 
dilakukan. Belum begitu baiknya tingkat cost efficiency bank-bank BUMN diduga karena menjalankan fungsi sebagai agen pembangunan sehingga mereka harus melakukan ekspansi usaha ke daerah-daerah yang tidak efisien dari skala usaha.

Dilihat dari sisi profit efficiency dan alternative profit efficiency, bank-bank yang beroperasi di Indonesia sudah relatif jauh lebih efisien dibandingkan dengan cost efficiency namun secara rata-rata tingkat efisiensi masih belum mencapai angka yang optimal. Bank-bank yang paling efisien berasal dari kelompok bank asing dan bank campuran. Hal ini disebabkan karena biasanya mereka sudah memiliki target pasar yang jelas. Mereka masuk ke Indonesia untuk mendukung usaha yang berasal dari kelompok atau negara tertentu. Usaha yang didukung oleh bankbank asing dan bank-bank campuran adalah usaha sangat besar dengan cakupan multinasional. Dengan biaya yang relatif kecil bank asing dan bank campuran bisa mendapatkan pendapatan dan keuntungan yang lebih besar dibandingkan bank dari kelompok lainnya.

Masih rendahnya tingkat efisiensi bank-bank yang beroperasi di Indonesia terutama bank-bank besar dengan market share yang sangat besar dan luas akan menimbulkan high cost economy dalam sistem perekonomian nasional. Oleh karena itu, terkait tingkat efisiensi yang masih rendah ini pemerintah bersama OJK harus bisa menilai secara objektif. Pemerintah bersama OJK harus bisa membedakan mana bank yang tidak efisien karena operasional usahanya tidak efisien dan mana bank yang tidak efisien karena sedang melakukan ekspansi usaha. Bank yang tidak efisien karena melakukan ekspansi usaha kemungkinan ketidakefisienannya tersebut berlangsung sementara. Untuk bank yang sedang melakukan ekspansi usaha, pemerintah beserta OJK sebaiknya memberikan waktu sampai ekspansi usaha selesai dan setelah itu pemerintah dan OJK bisa mendorong bank-bank tersebut supaya beroperasi secara efisien. Sebaliknya, untuk bank-bank yang tidak efisien dan tidak melakukan ekspansi, pemerintah bersama OJK harus segera mendorong mereka supaya bisa lebih efisien melalui berbagai instrumen yang dimiliki.

Bank-bank yang tidak efisien dari sisi keuntungan baik profit efficiency maupun alternative profit efficiency yang disebabkan karena bank tersebut menjalankan fungsi sebagai agen pembangunan dengan masuk ke daerah dan sektor yang kurang menguntungkan haras dimaklumi oleh pemerintah dan OJK. Bahkan alangkah lebih baiknya jika pemerintah bersama OJK memberikan insentif kepada bank-bank seperti ini.

Sambil mendorong bank-bank supaya lebih efisien baik dari sisi cost efficiency, profit efficiency, dan alternative profit efficiency, pemerintah bersama OJK sebaiknya membuat peraturan yang membatasi masuknya bank-bank asing atau pemodal-pemodal asing ke dalam industri perbankan Indonesia. Kebijakan ini digunakan untuk menunggu sampai industri perbankan nasional efisien dan siap bersaing dengan bank-bank asing yang akan masuk ke Indonesia yang tingkat efisiensinya lebih tinggi dibandingkan bank-bank nasional saat ini.

Pemerintah bersama OJK melalui instrumen yang dimilikinya haras memberikan reward dan punishment bagi bank-bank yang efisien dan tidak efisien terutama untuk bank-bank besar yang mengusai market share industri perbankan nasional. Hal ini dilakukan supaya bank-bank besar bisa menurunkan cost of fund-nya sehingga suku bunga kredit bisa lebih rendah. Dengan rendahnya suku bunga kredit bankbank besar maka perekonomian Indonesia bisa berdaya saing dan akan mampu bersaing dalam kancah persaingan global. Perekonomian Indonesia akan semakin meningkat seiring dengan meningkatnya produktivitas dan efisiensi sektor industri nasional yang disebabkan oleh efisiennya lembaga perbankan.

\section{REFERENCE}

Abidin, Z., Endri. 2009. Kinerja Efisiensi Teknis Bank Pembangunan Daerah: Pendekatan Data Envelopment Analysis (DEA). Jurnal Akuntansi dan Keuangan Vol. 11. No.1: 21-29.

Akhtar MH. 2010. E-Efficiency Analysis of Pakistani Commercial Banks. International Management Review 6(1):12-24.

Berger AN., Hunter, WC., Timme, SG. 1993. The Efficiency of Financial Institutions: A Review and Preview of Research Past, Present, and Future. Journal of Banking and Finance 17:221-249.

Berger AN., Humprey DB. 1997. Efficiency of Financial Institution: International Survey and Direction for Future Research. fic.wharton.upenn.edu/. [7 Februari2013].

Berger AN. Mester LJ. 1997. Inside the Black Box: What Explains Differences in The Efficiencies of Financial Institutions. fic.wharton.upenn.edu/. [7 Februari 2013].

Coelli, TJ., Rao, DSP., O'Donnell, CJ., Battese, G. 1998. An Introduction to Efficiency and Productivity Analysis. Kluwer Academic Publisher.

Degl'Innocenti, M., Matousek, R., Sevic, Z., Tzeremes, NG. 2017. Bank efficiency and financial centres: Does 
p-ISSN : 2655-7304

e-ISSN : 6655-8953

geographical location matter. Journal of International Financial Market, Institutions and Money 46: 188 - 198.

Delis, M., Iosifidi, M., and Tsionas, MG. 2017. Endogenous bank risk and efficiency.

European Journal of Operational Research 260: 376 - 387.

Dong, Y., Girardone, C., and Kuo JM. 2017. Governance, efficiency and risk taking in Chinese banking. The British Accounting Review 49: 211 - 229.

Endri. 2015. Variabel Makroekonomi Dan Efisiensi Perbankan Di Indonesia. Seminar Nasional Ekonomi Manajemen dan Akuntansi. Universitas Negeri Padang.

Farrel MJ. 1957. The Measurement of Productive Efficiency. http://www.jstor.org/stable/2343100. [1 Januari 2013].

Hadad MD., Santoso, W., Ilyas, D., Mardanugraha, E. 2003. Pendekatan Parametrik untuk Efisiensi Perbankan Indonesia. http://www.bi.go.id. [5 Juli 2012].

Hidayati, N., Siregar, H., Pasaribu, SH., 2015. Islamic Banking: Banking Efficiency Analysis in Indonesia. International Journal of Science and Research (IJSR) Vol.5, Issue 12: 1907-1910

Koopmans T. 1951. Activity analysis of production and allocation. John Wiley \& Sons, New York

Nurboja, B. and Kosak, M. 2017. Banking efficiency in South East Europe: Evidence for Financial crises and the gap between new EU members and candidate countries. Economic Systems 41: 122 - 138

Otoritas Jasa Keuangan. 2016. Statistik Perbankan Indonesia (SPI) bulan Agustus 2016. http:// www.ojk.go.id. [24 Desember 2016].

Repkova I. Miglietti CL. 2014. Cost and Profit Efficiency of The Slovak Banking Sector. http://icfb.rs.opf.slu.cz/. [10 Juli 2014].

Sari, PZ., Saraswati, E. 2017. The Determinant of Banking Efficiency in Indonesia (DEA Approach). Journal Of Accounting And Business Education, 1 (2): 208229.

Sealey, C. And Lindley, J. 1977. Inputs, Outputs, and a theory of production and cost at depository financial institutions. Journal of Finance 32:1251-1266.

Sekretariat Negara. 1998. Undang-Undang Republik Indonesia No. 10 Tahun 1998 tentang Perubahan atas Undang-Undang No. 7 Tahun 1992 tentang Perbankan. Jakarta.

Sillah, BMS., Khokhar, I., Khan, MN., 2014. The Performance of Saudi Banking Industry 2000 -2011: Have the Banks Distinguished Themselves from One Another?. International Journal of Financial Research. www.sciedu.ca/ijfr. [10 Juli 2014].

Thilakaweera, BH., Harvie, C., Arjomandi, A., 2016. Branch expansion and banking efficiency in Sri Lanka's postconflict era. Journal of Asian Economics 47: 45-57.

Triki, T., Kouki, I., Dhaou, MB., and Pietro. 2017. Bank regulation and efficiency: What works for Africa? Research in International Business and Finance 39:183 - 205.

Tsionas, EG., and Mamatzakis, EC., 2017. Adjustment costs in the technical efficiency: An application to global banking. European Journal of Operational Research 256: 640 - 649

Zuhroh, I., Ismail, M., Maskie, G. 2015. Cost Efficiency of Islamic Bank in Indonesia - Stochastic Frontier Analysis. Procedia - Social and Behavioral Sciences 211:1.122-1.131 